\title{
RESPONSE OF LANTANA CAMARA PLANTS TO FOLIAR APPLIED CITRIC ACID FOR DECREASING THE HARMFUL EFFECT OF HEAVY METALS POLLUTION IN THE IRRIGATION WATER (B) EFFECT OF NICKEL
}

\author{
N.A. El-Shanhorey ${ }^{*}$ and O.N. Emam** \\ * Botanical Gardens Research Department, Horticultural Research Institute, ARC, Alexandria, Egypt \\ ** Horticultural Department, Faculty of Agriculture, Beni-Suif University, Egypt
}

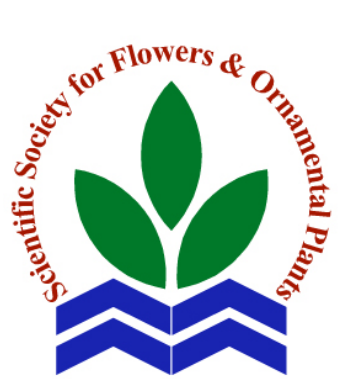

Scientific J. Flowers \& Ornamental Plants, 7(2):77-92 (2020).

Received: 8/4/2020

Accepted: $3 / 5 / 2020$

\begin{abstract}
The present study was carried-out at Antoniadis Research Branch, Horticultural Research Institute, Agriculture Research Center (ARC), Alexandria, Egypt during two successive seasons of 2018 and 2019. The aim of this study was to evaluate the effects of irrigation water polluted with nickel on the growth of Lantana camara plants and the possibility of using citric acid spray treatments to overcome the effects of nickel pollution. Transplants of Lantana camara were planted individually in plastic pots $(20 \mathrm{~cm}$ diameter) filled with $5 \mathrm{~kg}$ of sandy soil. The nickel polluted irrigation water treatments were $0,100,200$ and $300 \mathrm{mg} / \mathrm{l}$. The plants were monthly sprayed with citric acid at concentrations of 0,250 and 500 $\mathrm{mg} / \mathrm{l}$. The results showed that for vegetative growth parameters there were non significant differences in the interaction between nickel concentrations and foliar spray with citric acid, while significant reduction was observed in all parameters after irrigation with nickel polluted water and significant increase in vegetative growth parameters were observed after $500 \mathrm{mg} / \mathrm{l}$ citric acid application. For total chlorophyll and carbohydrate content, the highest significant values were obtained in plants irrigated with tap water and sprayed with 250 $\mathrm{mg} / \mathrm{l}$ citric acid while the highest significant level of nickel content in the leaves, stem and roots was obtained due treatment by $300 \mathrm{mg} / \mathrm{l}$ nickel without application of citric acid.
\end{abstract}

Key words: Lantana camara, polluted irrigation water, nickel, citric acid.

\section{INTRODUCTION}

Phytoremediation has become an effective and affordable technological solution used to extract or remove toxic metals from polluted soil. Phytoremediation is the use of plants to clean up a pollution from soils, sediments and water. This technology is environment friendly and potentially cost effective. Plants with exceptional metal-accumulating capacity are known as hyperaccumulator plants (Choruk et al., 2006). Plants need trace amount of heavy metals but their excessive availability may cause plant toxicity (Sharma et al.,
2006). Phytotoxic concentration of heavy metals referred in the literature does not always specify the levels (Wua et al., 2010).

Nickel is also released into the environment from anthropogenic activities, such as industrial wastes, fertilizer application and organic manures (Salt, 2000). Nickel is mainly used as a row material in the metallurgical and electroplating industries, and from sewage sludge and compost (Karam, 1998). Nickel is essential for plants (Ragsdale, 1998), It has been identified as a component of a number of enzymes, including glyoxalases, peptide 
deformylases and a few superoxide dismutases and hydrogenases (Küpper and Kroneck, 2007). Therefore, nickel plays a role in various important metabolic processes, including ureolysis, hydrogen metabolism, methane biogenesis and acitogensis (Mulrooney and Hausinger, 2003). Nickel has a particular toxicity due to its increasing industrial use, with increasing nickel pollution, excess nickel rather than a deficiency, is more commonly found in plants (Salt, 2000). Toxic effects of high concentrations of nickel in plants have been frequently reported, for example inhibition of mitotic activities (MadhavaRao and Sresty, 2000), reductions in plant growth (Molas, 2002) and adverse effects on fruit yield and quality (Gajewska et al., 2006). Extremely high soil nickel concentrations have left some farmland unsuitable for growing crops, fruits and vegetables (Duarte et al., 2007).

Endogenous organic acids are the source of both carbon skeleton and energy for cells and are used in the respiratory cycle and other biochemical pathways (Da Silva, 2003). Citric acid (CA) is an organic acid mainly served as antioxidant and involved in plant metabolism through its role in Krebs cycle during the respiration in mitochondria which produces cellular energy by oxidative phosphorylation (Taize and Zaiger, 2002). This energy is required for different physiological processes and development the mechanisms of resistance systems under different stressful factors. It is created by addition of acetyl-CoA to oxaloacetic acid that is converted to succinate and malate in next steps (Wills et al., 1981).

Lantana camara plant is found mostly in South India, in sub-tropical and tropical America and in Africa. The plant named Lantana camara Linn. Family: Verbenaceae is commonly known as wild sage or red sage and lantana weed. It is a large scrambling evergreen, strong smelling shrub with stout prickles, its leaves are opposite on both sides. Lantana flowers are small, generally orange but often vary in colors from white to dark red, which are prominently capitates in heads; bracts conspicuous and persistent. Lantana fruits are small, $5 \mathrm{~mm}$ diameter, drupaceous and shining, blue, greenish, blackish, with two nutlets in it. Its seeds were germinated easily throughout central and South India in most dry stony hills and black Lantana camara is a small perennial shrub which can grow to around $2 \mathrm{~m}$ in height and forms dense thickets in a variety of habitats. Due to extensive selective breeding throughout the $17^{\text {th }}$ and $18^{\text {th }}$ Century for use as an ornamental plant there are now many forms of Lantana camara present throughout the world (Ashwini et al., 2014).

In this study Lantana camara was selected due to its characteristics as nonedible plant which can grow in tropical areas and it has many uses in landscaping. Therefore, the objectives of this study were to determine the potential of Lantana camara in removing nickel from soil affected by nickel contaminated irrigation water and to investigate on the ability of Lantana camara in removing nickel.

\section{MATERIALS AND METHODS}

The present study was carried-out at Antoniades Research Branch, Horticultural Research Institute, Agriculture Research Center (ARC), Alexandria, Egypt during two successive seasons of 2018 and 2019.

On 15 $5^{\text {th }}$ of February, 2018 and 2019 in the first and second seasons, respectively, uniform transplants of Lantana camara (15$20 \mathrm{~cm}$ height and 10-15 leaves per plant) were planted individually in plastic pots (20 $\mathrm{cm}$ diameter) filled with $5 \mathrm{~kg}$ sandy soil. The chemical characteristics of the soil were measured as described by Jackson (1958) and presented in Table (1).

On $1^{\text {st }}$ of March (in both seasons), the polluted of irrigation water were initiated. Four concentrations of nickel chloride $\left(\mathrm{NiCl}_{2} \cdot 6 \mathrm{H}_{2} \mathrm{O}\right): 0,100,200$ and $300 \mathrm{mg} / \mathrm{l}$ were dissolved in the irrigation water. The plants were irrigated three times per week. At the end of the experiment every pot had received 
about 127 liters of nickel polluted water (Table, 2). In both seasons, the plants received monthly sprayed citric acid from $15^{\text {th }}$ May till $15^{\text {th }}$ August in both seasons at concentrations of 0,250 and $500 \mathrm{mg} / \mathrm{l}$. The control plants were sprayed with tap water. On $30^{\text {th }}$ of September in the both seasons, the plants were harvested.

In the two seasons, the plants received $\mathrm{N}, \mathrm{P}$ and $\mathrm{K}$ chemical fertilizers in the form of soluble fertilizer (Kristalon 19-19-19) at rate of $1.5 \mathrm{~g} /$ pot. Fertilization was repeated every 30 days throughout the growing season (from the $1^{\text {st }}$ of March till the $30^{\text {th }}$ of September). In addition, weeds were removed manually upon emergence.

\section{Data recorded:}

\section{Vegetative growth parameters:}

Plant height $(\mathrm{cm})$, number of leaves per plant, leaves dry weight per plant (g), leaves area $\left(\mathrm{cm}^{2}\right)$ according to Koller (1972), branch number per plant, stem diameter $(\mathrm{cm})$, stem dry weight $(\mathrm{g})$, root length $(\mathrm{cm})$, root dry weight (g), flower number per plant and flower dry weight (g) were also measured.

\section{Chemical analysis:}

- Total chlorophyll index was measured as a SPAD for the fresh middle leaves of plants, for the different treatments under the experiment at the end of the season using Minolta (chlorophyll meter) SPAD 502 according to Yadava (1986).

- Total carbohydrate percentage in the leaves was determined according to Dubios et al. (1956).

- Proline content (mg/g) in the leaves was determined according to Bates et al. (1973).

- Determination of nickel content in plant samples was determined as follows: Plant samples were divided into leaves, stem and roots, oven dried at $70{ }^{\circ} \mathrm{C}$ for $72 \mathrm{hrs}$ in an oven. The dried plant samples were ground to powder. The oven dried samples were digested for extraction of nickel, using the method described by Piper (1947) and the concentration of heavy metal was assured using an atomic absorption spectrophotometer.

- Available nickel in the soil sample was extracted by DPTA-Solution according to Lindsay and Norvell (1978) and measured by Inductively Coupled Plasma Spectrometry.

- Transfer factor (TF) is calculated as the ratio between the concentrations of metal in the shoots to the concentration of metal in the soil (Chen et al., 2004), as indicates to the efficiency of any plant to transfer any metal from soil to the aerial parts.

The pot experimental design was split plot with three replicates. Each replicate contained three plants. The main plot was

Table 1. The chemical properties of the used sandy soil for the two seasons 2018 and 2019.

\begin{tabular}{|c|c|c|c|c|c|c|c|c|c|}
\hline \multirow[t]{2}{*}{ Season } & \multirow[t]{2}{*}{ pH } & \multirow{2}{*}{$\begin{array}{c}\text { EC } \\
\mathbf{d S} / \mathbf{m}\end{array}$} & \multicolumn{4}{|c|}{$\begin{array}{c}\text { Water soluble cations } \\
\text { (meq/l) }\end{array}$} & \multicolumn{3}{|c|}{$\begin{array}{c}\text { Water soluble anions } \\
\text { (meq/l) }\end{array}$} \\
\hline & & & $\mathbf{C a}^{++}$ & $\mathrm{Mg}^{++}$ & $\mathrm{Na}^{+}$ & $\mathbf{K}^{+}$ & $\mathrm{HCO}_{3}{ }^{-}$ & $\mathrm{Cl}^{-}$ & $\mathrm{SO}_{4}^{--}$ \\
\hline 2018 & 7.93 & 1.55 & 3.4 & 3.4 & 6.5 & 1.3 & 3.6 & 6.7 & 2.4 \\
\hline 2019 & 7.91 & 1.52 & 3.2 & 3.0 & 6.3 & 1.2 & 3.3 & 6.5 & 2.2 \\
\hline
\end{tabular}

Table 2. Total amount of used irrigation water for each plant (l/pot) in each treatment during the two growing seasons of 2018 and 2019.

\begin{tabular}{ccccccccc}
\hline $\begin{array}{c}\text { Field } \\
\text { Capacity } \\
\text { (\%) }\end{array}$ & March & April & May & June & July & August & September & Total \\
\hline $\mathbf{1 0 0 \%}$ & 14.00 & 15.00 & 16.00 & 17.00 & 20.00 & 23.00 & 22.00 & 127.00 \\
\hline
\end{tabular}


nickel polluted water concentration, while the subplot was citric acid treatments. The obtained data were subjected to analysis of variance (ANOVA) using the SAS program, SAS Institute (SAS Institute, 2002). The Means of the individual factors and their interactions were compared by L.S.D test at $5 \%$ level of probability according to Snedecor and Cochran (1989).

\section{RESULTS}

\section{Vegetative growth:}

\section{a. Leaves parameters:}

Data presented in Table (3) showed that, in both seasons, irrigation water polluted with nickel decreased the tested leaves parameters of Lantana camara plants. However, plants irrigated with tap water (control) had the highest mean values of number of leaves per plant (95.50 and 94.99), leaves dry weight (1.71 and $2.06 \mathrm{~g}$ ) and leaves area (412.54 and $267.21 \mathrm{~cm}^{2}$ ) in the first and second seasons, respectively.
Increasing the nickel concentration significantly reduced in the tested parameters. The highest nickel concentration (300 mg/l) significantly produced the lowest plants mean values of plant number of leaves per plant (84.88 and 85.21), leaves dry weight (1.50 and $1.85 \mathrm{~g}$ ) and leaves area (232.58 and $191.90 \mathrm{~cm}^{2}$ ) in the first and second seasons, respectively, compared with the other concentrations.

Leaves parameters were also significantly affected by spraying the plants with citric acid. In both seasons, leaves parameters were gradually increased when the citric acid concentration was increased from $0 \mathrm{mg} / \mathrm{l}$ (control) to $500 \mathrm{mg} / \mathrm{l}$. Accordingly, Table (3) showed that plants sprayed with $500 \mathrm{mg} / \mathrm{l}$ citric acid showed significantly higher mean values of number of leaves per plant (92.24 and 92.41), leaves dry weight (1.65 and $2.01 \mathrm{~g})$ and leaves area (352.59 and $243.89 \mathrm{~cm}^{2}$ ) in the first and second seasons, respectively, compared with

Table 3. Means of number of leaves per plant, leaves dry weight (g) and leaves area $\left(\mathrm{cm}^{2}\right)$ of Lantana camara plants as influenced by nickel (Ni), citric acid (CA) and their combinations ( $\mathrm{Ni} \times \mathrm{CA})$ in the two seasons of 2018 and 2019.

\begin{tabular}{|c|c|c|c|c|c|c|c|}
\hline \multicolumn{2}{|c|}{ Treatments } & \multicolumn{2}{|c|}{$\begin{array}{c}\text { Number of leaves } \\
\text { per plant }\end{array}$} & \multicolumn{2}{|c|}{$\begin{array}{l}\text { Leaves dry weight } \\
\text { (g) }\end{array}$} & \multicolumn{2}{|c|}{$\begin{array}{l}\text { Leaves area } \\
\quad\left(\mathrm{cm}^{2}\right)\end{array}$} \\
\hline $\begin{array}{c}\mathrm{Ni} \\
(\mathrm{mg} / \mathrm{l})\end{array}$ & $\begin{array}{c}\text { CA } \\
(\mathbf{m g} / \mathbf{l})\end{array}$ & 2018 & 2019 & 2018 & 2019 & 2018 & 2019 \\
\hline \multirow{3}{*}{$\mathbf{0}$} & $\mathbf{0}$ & 93.50 & 94.08 & 1.71 & 2.06 & 391.00 & 272.44 \\
\hline & 250 & 95.50 & 95.08 & 1.67 & 2.01 & 360.35 & 251.86 \\
\hline & 500 & 97.50 & 95.83 & 1.77 & 2.13 & 486.27 & 277.33 \\
\hline \multirow{2}{*}{ Mean (Ni) } & & 95.50 & 94.99 & 1.71 & 2.06 & 412.54 & 267.21 \\
\hline & 0 & 91.50 & 92.58 & 1.64 & 2.01 & 349.93 & 231.86 \\
\hline \multirow[t]{2}{*}{100} & 250 & 90.50 & 91.58 & 1.62 & 1.97 & 332.13 & 226.02 \\
\hline & 500 & 95.50 & 95.58 & 1.72 & 2.06 & 350.24 & 236.47 \\
\hline \multirow{2}{*}{ Mean (Ni) } & & 92.50 & 93.25 & 1.66 & 2.01 & 344.10 & 231.45 \\
\hline & $\mathbf{0}$ & 88.83 & 89.83 & 1.57 & 1.92 & 307.15 & 236.43 \\
\hline \multirow[t]{2}{*}{200} & 250 & 86.00 & 85.83 & 1.53 & 1.91 & 301.72 & 206.61 \\
\hline & 500 & 89.83 & 90.58 & 1.60 & 1.95 & 309.14 & 256.33 \\
\hline \multirow[t]{2}{*}{ Mean (Ni) } & & 88.22 & 88.74 & 1.56 & 1.92 & 306.00 & 233.12 \\
\hline & 0 & 85.00 & 85.08 & 1.50 & 1.85 & 223.58 & 189.34 \\
\hline \multirow[t]{2}{*}{300} & 250 & 83.50 & 82.91 & 1.48 & 1.82 & 209.46 & 180.93 \\
\hline & 500 & 86.16 & 87.66 & 1.53 & 1.90 & 264.72 & 205.45 \\
\hline \multirow[t]{2}{*}{ Mean (Ni) } & & 84.88 & 85.21 & 1.50 & 1.85 & 232.58 & 191.90 \\
\hline & $\mathbf{0}$ & 89.70 & 90.39 & 1.60 & 1.96 & 317.91 & 232.51 \\
\hline \multirow[t]{3}{*}{ Mean (CA) } & 250 & 88.87 & 88.85 & 1.57 & 1.92 & 300.91 & 216.35 \\
\hline & 500 & 92.24 & 92.41 & 1.65 & 2.01 & 352.59 & 243.89 \\
\hline & $\mathrm{Ni}$ & 1.68 & 1.92 & 0.03 & 0.03 & 49.37 & 26.34 \\
\hline \multirow{2}{*}{ L.S.D. at 0.05} & CA & 1.95 & 1.70 & 0.04 & 0.04 & 26.80 & 15.79 \\
\hline & $\mathrm{Ni} \times \mathrm{CA}$ & 2.25 & 1.95 & 0.04 & 0.05 & 30.80 & 18.15 \\
\hline
\end{tabular}


the other concentrations.

Regarding the interaction between the irrigation with nickel polluted water and citric acid treatments on the tested leaves parameters, the recorded results in the two seasons showed that, the highest values were obtained from plants irrigated with tap water (control) and sprayed with citric acid at 500 $\mathrm{mg} / \mathrm{l}$ with mean values of number of leaves per plant (97.50 and 95.83), leaves dry weight (1.77 and $2.13 \mathrm{~g})$ and leaves area (486.27 and $277.33 \mathrm{~cm}^{2}$ ) in the first and second seasons, respectively, compared with the other concentrations. On the other hand, the lowest values of number of leaves per plant were (83.50 and 82.91), for leaves dry weight were (1.48 and $1.82 \mathrm{~g}$ ) and for leaves area were (209.46 and $180.93 \mathrm{~cm}^{2}$ ) in the first and second seasons, respectively, were resulted when the plants were irrigated using the highest nickel concentration (300 $\mathrm{mg} / \mathrm{l}$ ) and sprayed with citric acid at $250 \mathrm{mg} / \mathrm{l}$ treatment. It can be also showed that in many cases, spraying plants with citric acid reduced the adverse effect of polluted water with nickel (Table 3).

\section{b. Stem parameters:}

Data presented in Table (4) showed that irrigation with nickel polluted water decreased stem parameters, compared to those of plants irrigated with tap water (control). In both seasons, plants irrigated with tap water had the thickest stem, with mean plant height (32.99 and $38.61 \mathrm{~cm}$ ), number of branch per plant (6.33 and 11.33), stem diameter $(0.49$ and $0.66 \mathrm{~cm})$ and stem dry weight (3.01 and $5.03 \mathrm{~g}$ ) in the first and second seasons, respectively. Increasing the nickel concentration in irrigation water caused a steady reduction in stem parameters. This reduction in stem parameter was significant (compared to the control), even at the highest nickel concentration (300 $\mathrm{mg} / \mathrm{l})$, which gave plant height (29.02 and

Table 4. Means of plant height $(\mathrm{cm})$, branch number per plant, stem diameter $(\mathrm{cm})$ and stem dry weight (g) of Lantana camara plants as influenced by nickel ( $\mathrm{Ni}$ ), citric acid (CA) and their combinations ( $\mathrm{Ni} \times \mathrm{CA})$ in the two seasons of 2018 and 2019.

\begin{tabular}{|c|c|c|c|c|c|c|c|c|c|}
\hline \multicolumn{2}{|c|}{ Treatments } & \multicolumn{2}{|c|}{$\begin{array}{l}\text { Plant height } \\
\text { (cm) }\end{array}$} & \multicolumn{2}{|c|}{$\begin{array}{c}\text { Branch number } \\
\text { per plant }\end{array}$} & \multicolumn{2}{|c|}{$\begin{array}{l}\text { Stem diameter } \\
\text { (cm) }\end{array}$} & \multicolumn{2}{|c|}{$\begin{array}{l}\text { Stem dry weight } \\
\text { (g) }\end{array}$} \\
\hline$\underset{(\mathbf{m g} / \mathbf{l})}{\mathrm{Ni}}$ & $\begin{array}{c}\text { CA } \\
(\mathrm{mg} / \mathrm{l})\end{array}$ & 2018 & 2019 & 2018 & 2019 & 2018 & 2019 & 2018 & 2019 \\
\hline & $\mathbf{0}$ & 33.33 & 38.50 & 6.16 & 11.33 & 0.49 & 0.65 & 2.85 & 4.87 \\
\hline \multirow[t]{2}{*}{0} & 250 & 32.00 & 37.83 & 6.00 & 10.83 & 0.48 & 0.63 & 2.73 & 4.75 \\
\hline & 500 & 33.66 & 39.50 & 6.83 & 11.83 & 0.51 & 0.70 & 3.46 & 5.47 \\
\hline \multirow[t]{2}{*}{ Mean (Ni) } & & 32.99 & 38.61 & 6.33 & 11.33 & 0.49 & 0.66 & 3.01 & 5.03 \\
\hline & 0 & 32.00 & 37.16 & 5.83 & 9.83 & 0.46 & 0.62 & 2.47 & 4.02 \\
\hline \multirow[t]{2}{*}{100} & 250 & 31.00 & 36.83 & 5.66 & 9.66 & 0.44 & 0.61 & 2.43 & 3.95 \\
\hline & 500 & 32.66 & 38.50 & 6.00 & 10.66 & 0.47 & 0.66 & 2.61 & 4.40 \\
\hline \multirow[t]{2}{*}{ Mean (Ni) } & & 31.88 & 37.49 & 5.83 & 10.05 & 0.45 & 0.63 & 2.50 & 4.12 \\
\hline & 0 & 29.75 & 35.91 & 5.66 & 9.16 & 0.44 & 0.61 & 2.38 & 3.79 \\
\hline \multirow[t]{2}{*}{200} & 250 & 29.50 & 35.33 & 5.33 & 8.83 & 0.42 & 0.60 & 2.25 & 3.61 \\
\hline & 500 & 30.75 & 36.58 & 6.00 & 9.50 & 0.45 & 0.62 & 2.55 & 4.26 \\
\hline \multirow[t]{2}{*}{ Mean (Ni) } & & 30.00 & 35.94 & 5.66 & 9.16 & 0.43 & 0.61 & 2.39 & 3.88 \\
\hline & 0 & 28.83 & 35.00 & 5.16 & 8.66 & 0.39 & 0.55 & 2.41 & 3.68 \\
\hline \multirow[t]{2}{*}{300} & 250 & 28.66 & 34.50 & 4.83 & 7.83 & 0.37 & 0.54 & 2.06 & 3.58 \\
\hline & 500 & 29.58 & 35.75 & 5.33 & 9.00 & 0.41 & 0.56 & 2.53 & 4.25 \\
\hline \multirow[t]{2}{*}{ Mean (Ni) } & & 29.02 & 35.08 & 5.10 & 8.49 & 0.39 & 0.55 & 2.33 & 3.83 \\
\hline & 0 & 30.97 & 36.64 & 5.70 & 9.74 & 0.44 & 0.60 & 2.52 & 4.09 \\
\hline \multirow[t]{3}{*}{ Mean (CA) } & 250 & 30.29 & 36.12 & 5.45 & 9.28 & 0.42 & 0.59 & 2.36 & 3.97 \\
\hline & 500 & 31.66 & 37.58 & 6.04 & 10.24 & 0.46 & 0.63 & 2.78 & 4.59 \\
\hline & $\mathrm{Ni}$ & 0.75 & 0.48 & 0.41 & 1.81 & 0.04 & 0.03 & 0.22 & 0.79 \\
\hline \multicolumn{2}{|c|}{ L.S.D. at $0.05 \mathrm{CA}$} & 0.65 & 0.58 & 0.27 & 0.74 & 0.02 & 0.03 & 0.12 & 0.44 \\
\hline & $\mathrm{Ni} \times \mathrm{CA}$ & 0.74 & 0.66 & 0.31 & 0.85 & 0.02 & 0.03 & 0.13 & 0.50 \\
\hline
\end{tabular}


$35.08 \mathrm{~cm})$, number of branch per plant $(5.10$ and 8.49), stem diameter $(0.39$ and $0.55 \mathrm{~cm})$, and stem dry weight (2.33 and $3.83 \mathrm{~g}$ ) in the first and second seasons, respectively, compared with the other concentrations.

In contrast to the effect of nickel treatments, citric acid treatments improved stem parameters, compared to the control. Moreover, plants sprayed with $500 \mathrm{mg} / \mathrm{l}$ citric acid had significantly mean plant height (31.66 and $37.58 \mathrm{~cm}$ ), number of branch per plant (6.04 and 10.24), stem diameter $(0.46$ and $0.63 \mathrm{~cm})$ and stem dry weight ( 2.78 and $4.59 \mathrm{~g}$ ) in the first and second seasons, respectively, compared with the other concentrations.

Regarding the interaction between the irrigation with water nickel polluted and sprayed with citric acid on stem parameters of Lantana camara plants, the recorded results for the two seasons are presented that Table (4) showed that significant differences were detected between the values obtained from which plants received the different treatment combinations. The highest values of plant height (33.66 and $38.61 \mathrm{~cm}$ ), number of branch per plant (6.33 and 11.33), stem diameter $(0.51$ and $0.70 \mathrm{~cm})$ and stem dry weight (3.46 and $5.47 \mathrm{~g}$ ) in the first and second seasons, respectively, were obtained from the plants irrigated with tap water and sprayed with citric acid at $500 \mathrm{mg} / \mathrm{l}$. On the other hand, the least values of plant height (28.66 and $34.50 \mathrm{~cm}$ ), number of branch per plant (4.83 and 7.83), stem diameter (0.37 and $0.54 \mathrm{~cm}$ ) and stem dry weight (2.06 and $3.58 \mathrm{~g}$ ) in the first and second seasons, respectively, were obtained from plants irrigated with the highest nickel concentration $(300 \mathrm{mg} / \mathrm{l})$ and sprayed with citric acid at $250 \mathrm{mg} / \mathrm{l}$ treatment. Table (4) showed that, in many cases, spraying the plants with citric acid reduced the adverse effect of nickel polluted water.

\section{c. Root parameters:}

Data presented in Table (5) showed that irrigation with nickel polluted water decreased root parameters, compared to those of plants irrigated with tap water (control). In both seasons, plants irrigated with tap water had the highest values of root length (15.65 and $18.97 \mathrm{~cm}$ ) and root dry weight (1.98 and $3.34 \mathrm{~g}$ ) in the first and second seasons, respectively. Increasing nickel concentration in irrigation water caused a steady reduction in root parameters. These reductions were significant as compared to the control even at the highest nickel concentration (300 mg/l), which gave root length (13.82 and $17.12 \mathrm{~cm}$ ) and root dry weight (1.51 and $2.53 \mathrm{~g}$ ) in the first and second seasons, respectively.

In contrast to the effect of nickel treatments, citric acid treatments improved root parameters, compared to the control. Moreover, plants sprayed with $500 \mathrm{mg} / \mathrm{l}$ citric acid had significantly mean root length (15.09 and $18.39 \mathrm{~cm}$ ) and root dry weight (1.82 and $3.04 \mathrm{~g}$ ) in the first and second seasons, respectively, compared to either those of control plants, or plants sprayed with any other citric acid concentration.

Regarding the interaction between the irrigation with nickel polluted water and citric acid treatments on root parameters of Lantana camara plants, the results showed that significant differences were obtained between the values for plants receiving the different treatment combinations. The highest values of root length (15.99 and $19.32 \mathrm{~cm})$ and root dry weight (2.29 and $3.64 \mathrm{~g}$ ) in the first and second seasons, respectively, were obtained from the plants irrigated with tap water and sprayed with citric acid at $500 \mathrm{mg} / \mathrm{l}$. On the other hand, the lowest values of root length (14.42 and $17.73 \mathrm{~cm})$ and root dry weight (1.54 and $2.63 \mathrm{~g})$ in the first and second seasons, respectively, were obtained from the plants irrigated using the highest nickel concentration $300 \mathrm{mg} / \mathrm{l}$ and sprayed with citric acid at $250 \mathrm{mg} / \mathrm{l}$ treatment. It can be seen from Table (5) that in many cases, spraying the plants with citric acid reduced the harmful effect of nickel polluted water. 
Table 5. Means of root length $(\mathrm{cm})$ and root dry weight $(\mathrm{g})$ of Lantana camara plants as influenced by nickel (Ni), citric acid (CA) and their combinations ( $\mathrm{Ni} \times \mathrm{CA})$ in the two seasons of 2018 and 2019.

\begin{tabular}{|c|c|c|c|c|c|}
\hline \multicolumn{2}{|c|}{ Treatments } & \multicolumn{2}{|c|}{ Root length (cm) } & \multicolumn{2}{|c|}{ Root dry weight (g) } \\
\hline $\begin{array}{c}\mathrm{Ni} \\
(\mathrm{mg} / \mathrm{l})\end{array}$ & $\begin{array}{c}\text { CA } \\
(\mathrm{mg} / \mathrm{l})\end{array}$ & 2018 & 2019 & 2018 & 2019 \\
\hline & 0 & 15.66 & 18.97 & 1.86 & 3.24 \\
\hline \multirow[t]{2}{*}{$\mathbf{0}$} & 250 & 15.30 & 18.62 & 1.79 & 3.16 \\
\hline & 500 & 15.99 & 19.32 & 2.29 & 3.64 \\
\hline \multirow[t]{2}{*}{ Mean (Ni) } & & 15.65 & 18.97 & 1.98 & 3.34 \\
\hline & 0 & 14.96 & 18.27 & 1.61 & 2.67 \\
\hline \multirow[t]{2}{*}{100} & 250 & 14.79 & 18.10 & 1.58 & 2.61 \\
\hline & 500 & 15.65 & 18.96 & 1.71 & 2.92 \\
\hline \multirow[t]{2}{*}{ Mean (Ni) } & & 15.13 & 18.44 & 1.63 & 2.73 \\
\hline & 0 & 14.49 & 17.79 & 1.56 & 2.51 \\
\hline \multirow{2}{*}{200} & 250 & 14.02 & 17.31 & 1.47 & 2.40 \\
\hline & 500 & 14.66 & 17.96 & 1.66 & 2.82 \\
\hline \multirow[t]{2}{*}{ Mean (Ni) } & & 14.39 & 17.68 & 1.56 & 2.57 \\
\hline & $\mathbf{0}$ & 13.84 & 17.13 & 1.57 & 2.44 \\
\hline \multirow[t]{2}{*}{300} & 250 & 13.58 & 16.89 & 1.33 & 2.36 \\
\hline & 500 & 14.06 & 17.35 & 1.65 & 2.81 \\
\hline \multirow[t]{2}{*}{ Mean (Ni) } & & 13.82 & 17.12 & 1.51 & 2.53 \\
\hline & 0 & 14.73 & 18.04 & 1.65 & 2.71 \\
\hline \multirow[t]{3}{*}{ Mean (CA) } & 250 & 14.42 & 17.73 & 1.54 & 2.63 \\
\hline & 500 & 15.09 & 18.39 & 1.82 & 3.04 \\
\hline & $\mathrm{Ni}$ & 0.27 & 0.28 & 0.14 & 0.52 \\
\hline \multirow[t]{2}{*}{ L.S.D. at 0.05} & CA & 0.33 & 0.33 & 0.08 & 0.29 \\
\hline & $\mathrm{Ni} \times \mathrm{CA}$ & 0.38 & 0.38 & 0.09 & 0.34 \\
\hline
\end{tabular}

\section{d. Flowering parameters:}

Data presented in Table (6) showed that, in both seasons, irrigation with nickel polluted water decreased the flowering parameters of Lantana camara plants. Plants irrigated with tap water (control) had the highest mean values of number of flowers per plant (20.94 and 27.94) and flower dry weight (1.85 and $3.21 \mathrm{~g}$ ) in the first and second seasons, respectively. Increasing nickel concentration caused significant reductions in flowering parameters, with the highest nickel concentration (300 mg/l) giving significantly the smallest mean values of number of flower per plant (18.77 and 25.44) and flower dry weight (1.39 and 2.41 g) in the first and second seasons, respectively, compared with the other concentrations.

Flowering parameters were also significantly affected by spraying the plants with citric acid. In both seasons, they gradually increase was noticed with the increase of citric acid concentration. Accordingly, Table (6) showed that Lantana camara plants sprayed with $500 \mathrm{mg} / \mathrm{l}$ citric acid gave significantly increased the values of number of flowers per plant (20.33 and 27.16) and flower dry weight (1.70 and 2.92 g) in the first and second seasons, respectively, compared with the other concentrations.

Regarding the interaction between the irrigation with nickel polluted water and citric acid treatments on flowers parameters, the recorded results in the two seasons showed that, the highest values were obtained from the plants irrigated with tap water and sprayed with citric acid at 500 $\mathrm{mg} / \mathrm{l}$ with values of number of flower per plant (21.33 and 28.50) and flower dry weight $(2.17$ and $3.51 \mathrm{~g})$ in the first and second seasons, respectively. On the other hand, the plants with values of number of flower per plant (18.33 and 25.16) and flower dry weight (1.21 and $2.24 \mathrm{~g}$ ) in the 
Table 6. Means of flower number per plant and flower dry weight (g) of Lantana camara plants as influenced by nickel (Ni), citric acid (CA) and their combinations ( $\mathrm{Ni} \times$ CA) in the two seasons of 2018 and 2019.

\begin{tabular}{|c|c|c|c|c|c|}
\hline & nents & Flower & er plant & Flowe & ght (g) \\
\hline $\begin{array}{c}\mathrm{Ni} \\
(\mathrm{mg} / \mathrm{l})\end{array}$ & $\begin{array}{c}\text { CA } \\
(\mathrm{mg} / \mathrm{l})\end{array}$ & 2018 & 2019 & 2018 & 2019 \\
\hline & $\mathbf{0}$ & 21.00 & 28.00 & 1.73 & 3.10 \\
\hline $\mathbf{0}$ & 250 & 20.50 & 27.33 & 1.66 & 3.03 \\
\hline & 500 & 21.33 & 28.50 & 2.17 & 3.51 \\
\hline Mean (Ni) & & 20.94 & 27.94 & 1.85 & 3.21 \\
\hline & $\mathbf{0}$ & 20.16 & 27.00 & 1.50 & 2.54 \\
\hline 100 & 250 & 20.00 & 26.83 & 1.45 & 2.49 \\
\hline & 500 & 21.00 & 28.00 & 1.58 & 2.79 \\
\hline Mean (Ni) & & 20.38 & 27.27 & 1.51 & 2.60 \\
\hline & $\mathbf{0}$ & 19.66 & 26.33 & 1.45 & 2.40 \\
\hline 200 & 250 & 19.00 & 25.66 & 1.34 & 2.27 \\
\hline & 500 & 19.83 & 26.50 & 1.53 & 2.69 \\
\hline Mean (Ni) & & 19.49 & 26.16 & 1.44 & 2.45 \\
\hline & $\mathbf{0}$ & 18.83 & 25.50 & 1.45 & 2.30 \\
\hline 300 & 250 & 18.33 & 25.16 & 1.21 & 2.24 \\
\hline & 500 & 19.16 & 25.66 & 1.52 & 2.69 \\
\hline Mean (Ni) & & 18.77 & 25.44 & 1.39 & 2.41 \\
\hline & $\mathbf{0}$ & 19.91 & 26.70 & 1.53 & 2.58 \\
\hline Mean (CA) & 250 & 19.45 & 26.24 & 1.41 & 2.50 \\
\hline & 500 & 20.33 & 27.16 & 1.70 & 2.92 \\
\hline & $\mathrm{Ni}$ & 0.24 & 0.37 & 0.15 & 0.53 \\
\hline L.S.D. at 0.05 & CA & 0.47 & 0.47 & 0.08 & 0.29 \\
\hline & $\mathrm{Ni} \times \mathrm{CA}$ & 0.65 & 0.65 & 0.09 & 0.33 \\
\hline
\end{tabular}

first and second seasons, respectively, obtained found when the plants were irrigated with $300 \mathrm{mg} / \mathrm{l}$ nickel concentration water and sprayed with citric acid at 250 $\mathrm{mg} / \mathrm{l}$ treatment. It can also be seen from Table (6) that in many cases, spraying the plants with citric acid reduced the harmful effect of polluted water with nickel.

\section{Chemical composition:}

\section{a. Leaf chemical analysis:}

Data presented in Table (7) showed that the highest value of total chlorophyll was obtained from plant irrigated with tap water (55.17 and 55.65 SPAD) and of total carbohydrates (18.77 and 18.93\%) in the first and second seasons, respectively, while the maximum proline content (2.49 and 2.45 $\mathrm{mg} / \mathrm{g}$ ) was obtained from the plants irrigated with nickel contaminated water at (300 $\mathrm{mg} / \mathrm{l})$. Increasing the nickel concentration in irrigation water resulted in steady significant reductions in the chlorophyll and carbohydrates content, which reached its lowest mean value for chlorophyll (49.76 and 50.47 SPAD) and total carbohydrates (16.92 and $17.16 \%$ ) in the first and second seasons, respectively, for plants receiving the highest nickel concentration (300 mg/l), while, proline content values (1.33 and 1.36 $\mathrm{mg} / \mathrm{g}$ ) were obtained from the plants irrigated with tap water.

Data in Table (7) also showed that citric acid treatments had pronounced effect on leaf chlorophyll (54.85 and 55.30 SPAD) and total carbohydrates (18.66 and $18.81 \%$ ) in the first and second seasons, respectively, in plants sprayed with citric acid at $250 \mathrm{mg} / \mathrm{l}$, while, proline contents (1.99 and $2.02 \mathrm{mg} / \mathrm{g}$ ) were obtained in plants non sprayed with citric acid.

Regarding the interaction between the irrigation using nickel polluted water and citric acid treatments, Table (7) showed that the highest total chlorophyll contents (56.83 and 57.20 SPAD) and total carbohydrates (19.34 and $19.46 \%$ ) in the first and second 
Table 7. Means of chlorophyll content (SPAD), carbohydrates content (\%) and proline content (mg/g d.w.) of Lantana camara plants as influenced by nickel (Ni), citric acid (CA) and their combinations ( $\mathrm{Ni} \times \mathrm{CA})$ in the two seasons of 2018 and 2019.

\begin{tabular}{|c|c|c|c|c|c|c|c|}
\hline \multicolumn{2}{|c|}{ Treatments } & \multicolumn{2}{|c|}{$\begin{array}{l}\text { Chlorophyll content } \\
\text { (SPAD) }\end{array}$} & \multicolumn{2}{|c|}{$\begin{array}{c}\text { Carbohydrates content } \\
(\%)\end{array}$} & \multicolumn{2}{|c|}{$\begin{array}{l}\text { Proline content } \\
\text { (mg/g d.w.) }\end{array}$} \\
\hline $\begin{array}{c}\mathrm{Ni} \\
(\mathrm{mg} / \mathrm{l})\end{array}$ & $\begin{array}{c}\text { CA } \\
(\mathrm{mg} / \mathrm{l})\end{array}$ & 2018 & 2019 & 2018 & 2019 & 2018 & 2019 \\
\hline \multirow{3}{*}{ 0 } & $\mathbf{0}$ & 53.50 & 54.22 & 18.20 & 18.44 & 1.39 & 1.41 \\
\hline & 250 & 56.83 & 57.20 & 19.34 & 19.46 & 1.36 & 1.39 \\
\hline & 500 & 55.18 & 55.54 & 18.77 & 18.89 & 1.25 & 1.30 \\
\hline \multirow[t]{2}{*}{ Mean (Ni) } & & 55.17 & 55.65 & 18.77 & 18.93 & 1.33 & 1.36 \\
\hline & 0 & 49.67 & 50.05 & 16.90 & 17.02 & 1.84 & 1.89 \\
\hline \multirow[t]{2}{*}{100} & 250 & 56.41 & 56.78 & 19.19 & 19.31 & 1.81 & 1.83 \\
\hline & 500 & 54.63 & 55.38 & 18.58 & 18.84 & 1.80 & 1.82 \\
\hline \multirow[t]{2}{*}{ Mean (Ni) } & & 53.57 & 54.07 & 18.22 & 18.39 & 1.81 & 1.84 \\
\hline & 0 & 48.07 & 49.08 & 16.35 & 16.70 & 2.26 & 2.31 \\
\hline \multirow{2}{*}{200} & 250 & 54.00 & 54.38 & 18.37 & 18.50 & 2.24 & 2.28 \\
\hline & 500 & 53.08 & 53.45 & 18.06 & 18.18 & 2.21 & 2.27 \\
\hline \multirow[t]{2}{*}{ Mean (Ni) } & & 51.71 & 52.30 & 17.59 & 17.79 & 2.23 & 2.28 \\
\hline & 0 & 47.03 & 48.07 & 15.99 & 16.35 & 2.50 & 2.48 \\
\hline \multirow{2}{*}{300} & 250 & 52.16 & 52.86 & 17.74 & 17.98 & 2.49 & 2.45 \\
\hline & 500 & 50.10 & 50.49 & 17.04 & 17.17 & 2.48 & 2.44 \\
\hline \multirow[t]{2}{*}{ Mean (Ni) } & & 49.76 & 50.47 & 16.92 & 17.16 & 2.49 & 2.45 \\
\hline & o & 49.56 & 50.35 & 16.86 & 17.12 & 1.99 & 2.02 \\
\hline \multirow[t]{3}{*}{ Mean (CA) } & 250 & 54.85 & 55.30 & 18.66 & 18.81 & 1.97 & 1.98 \\
\hline & 500 & 53.24 & 53.71 & 18.11 & 18.27 & 1.93 & 1.95 \\
\hline & $\mathbf{N i}$ & 0.51 & 0.48 & 0.17 & 0.16 & 0.05 & 0.04 \\
\hline \multirow{2}{*}{ L.S.D. at 0.05} & CA & 0.38 & 0.37 & 0.13 & 0.12 & 0.02 & 0.01 \\
\hline & $\mathrm{Ni} \times \mathrm{CA}$ & 0.44 & 0.43 & 0.15 & 0.14 & 0.02 & 0.01 \\
\hline
\end{tabular}

seasons, respectively, were found in leaves of plants irrigated with tap water and sprayed with citric acid at $250 \mathrm{mg} / \mathrm{l}$, while, proline contents (2.50 and $2.48 \mathrm{mg} / \mathrm{g}$ ) were resulted from the plants irrigated with the highest nickel concentration (300 mg/l) without citric acid treatment.

\section{b. Nickel content in leaves, stem and root (mg/l):}

Data presented in Table (8) showed that, the nickel content $(\mathrm{mg} / \mathrm{l})$ in the dried plant parts was increased with increasing the nickel concentration in the irrigation water. Generally, the lowest mean nickel content of the leaves $(0.102$ and $0.263 \mathrm{mg} / \mathrm{l})$, stem (0.142 and $0.160 \mathrm{mg} / \mathrm{l})$ and root (0.056 and $0.043 \mathrm{mg} / \mathrm{l})$ in the first and second seasons, respectively, were registered in leaves of plants irrigated with tap water, whereas the highest mean values of nickel content of the leaves (0.914 and $0.954 \mathrm{mg} / \mathrm{l})$, stem (0.546 and $0.616 \mathrm{mg} / \mathrm{l})$ and root (0.421 and 0.461 $\mathrm{mg} / \mathrm{l})$ in the first and second seasons, respectively, were recorded in plants irrigated with water containing the highest nickel concentration (300 mg/l).

Concerning the effect of citric acid treatments on the nickel content in plant parts, Table (8) showed that citric acid treatment of $500 \mathrm{mg} / \mathrm{l}$ caused a significant decrease in the mean values of nickel content in the leaves $(0.545$ and $0.632 \mathrm{mg} / \mathrm{l})$, stem (0.371 and $0.408 \mathrm{mg} / \mathrm{l})$ and root $(0.272$ and $0.294 \mathrm{mg} / \mathrm{l}$ ) in the first and second seasons, respectively, compared to that of control plants had the highest nickel content in the leaves $(0.600$ and $0.689 \mathrm{mg} / \mathrm{l})$, stem $(0.390$ and $0.431 \mathrm{mg} / \mathrm{l})$ and root $(0.288$ and 0.306 $\mathrm{mg} / \mathrm{l}$ ) in the first and second seasons, respectively.

Concerning the interaction between irrigation using nickel polluted water with 
Table 8. Means of nickel content of Lantana camara plants as influenced by nickel (Ni), citric acid (CA) and their combinations ( $\mathrm{Ni} \times \mathrm{CA}$ ) in the two seasons of 2018 and 2019.

\begin{tabular}{|c|c|c|c|c|c|c|c|}
\hline \multicolumn{2}{|c|}{ Treatments } & \multicolumn{2}{|c|}{$\begin{array}{l}\text { Nickel content in leaves } \\
(\mathrm{mg} / \mathrm{kg})\end{array}$} & \multicolumn{4}{|c|}{$\begin{array}{l}\text { Nickel content in stem Nickel content in roots } \\
(\mathrm{mg} / \mathrm{kg})\end{array}$} \\
\hline$\underset{(\mathrm{mg} / \mathrm{l})}{\mathrm{Ni}}$ & $\begin{array}{c}\mathrm{CA} \\
(\mathrm{mg} / \mathrm{l})\end{array}$ & 2018 & 2019 & 2018 & 2019 & 2018 & 2019 \\
\hline \multirow{3}{*}{$\mathbf{0}$} & 0 & 0.154 & 0.311 & 0.145 & 0.168 & 0.061 & 0.048 \\
\hline & 250 & 0.092 & 0.252 & 0.143 & 0.166 & 0.057 & 0.044 \\
\hline & 500 & 0.061 & 0.226 & 0.139 & 0.146 & 0.051 & 0.038 \\
\hline \multirow[t]{2}{*}{ Mean (Ni) } & & 0.102 & 0.263 & 0.142 & 0.160 & 0.056 & 0.043 \\
\hline & 0 & 0.476 & 0.633 & 0.346 & 0.416 & 0.267 & 0.321 \\
\hline \multirow[t]{2}{*}{100} & 250 & 0.458 & 0.615 & 0.338 & 0.408 & 0.261 & 0.315 \\
\hline & 500 & 0.414 & 0.572 & 0.318 & 0.388 & 0.246 & 0.300 \\
\hline \multirow[t]{2}{*}{ Mean (Ni) } & & 0.449 & 0.606 & 0.334 & 0.404 & 0.258 & 0.312 \\
\hline & 0 & 0.848 & 0.845 & 0.511 & 0.511 & 0.394 & 0.394 \\
\hline \multirow[t]{2}{*}{200} & 250 & 0.816 & 0.813 & 0.497 & 0.495 & 0.385 & 0.383 \\
\hline & 500 & 0.796 & 0.802 & 0.488 & 0.491 & 0.377 & 0.379 \\
\hline \multirow[t]{2}{*}{ Mean (Ni) } & & 0.820 & 0.820 & 0.498 & 0.499 & 0.385 & 0.385 \\
\hline & 0 & 0.923 & 0.969 & 0.561 & 0.629 & 0.433 & 0.462 \\
\hline \multirow[t]{2}{*}{300} & 250 & 0.912 & 0.966 & 0.540 & 0.613 & 0.417 & 0.461 \\
\hline & 500 & 0.909 & 0.928 & 0.539 & 0.608 & 0.415 & 0.460 \\
\hline \multirow{2}{*}{ Mean (Ni) } & & 0.914 & 0.954 & 0.546 & 0.616 & 0.421 & 0.461 \\
\hline & 0 & 0.600 & 0.689 & 0.390 & 0.431 & 0.288 & 0.306 \\
\hline \multirow[t]{3}{*}{ Mean (CA) } & 250 & 0.569 & 0.661 & 0.379 & 0.420 & 0.280 & 0.300 \\
\hline & 500 & 0.545 & 0.632 & 0.371 & 0.408 & 0.272 & 0.294 \\
\hline & $\mathbf{N i}$ & 0.067 & 0.056 & 0.026 & 0.029 & 0.029 & 0.023 \\
\hline \multirow{2}{*}{ L.S.D. at 0.05} & CA & 0.059 & 0.042 & 0.029 & 0.019 & 0.023 & 0.019 \\
\hline & $\mathrm{Ni} \times \mathrm{CA}$ & 0.067 & 0.048 & 0.032 & 0.022 & 0.026 & 0.022 \\
\hline
\end{tabular}

nickel and citric acid treatments on the nickel content in plant parts, Table (8) showed that the lowest mean values of nickel content in the leaves $(0.061$ and $0.226 \mathrm{mg} / \mathrm{l})$, stem (0.139 and $0.146 \mathrm{mg} / \mathrm{l})$ and root $(0.051$ and $0.038 \mathrm{mg} / \mathrm{l})$ in the first and second seasons, respectively, were of found in plants irrigated with tap water and sprayed with citric acid at $500 \mathrm{mg} / \mathrm{l}$. On the other hand, the highest nickel content was obtained in the plant parts irrigated with nickel water at (300 mg/l) and receiving no citric acid treatment nickel content in the leaves $(0.923$ and $0.969 \mathrm{mg} / \mathrm{l})$, stem (0.561 and 0.629 $\mathrm{mg} / \mathrm{l})$ and root $(0.433$ and $0.462 \mathrm{mg} / \mathrm{l})$.

\section{c. Transfer factor (TF) of heavy metals:}

\section{Nickel content in soil samples} (mg/kg):

Data presented in Table (9) showed that the lowest average value of nickel content was in untreated soil, while the highest was observed in $300 \mathrm{mg} / \mathrm{l}$ nickel treated soil and $0 \mathrm{mg} / \mathrm{l}$ citric acid.

\section{Transfer factor to leaves, stem and root:}

Data presented in Table (10), showed that the transfer factor (TF) in the dried plant parts of Lantana camara plants was steadily decreased with increasing nickel concentration in irrigation water. Accordingly, the lowest nickel values in leaves (1.069 and $2.477 \mathrm{mg} / \mathrm{l})$, stem (1.396 and $1.487 \mathrm{mg} / \mathrm{l})$ and root (0.558 and 0.405 $\mathrm{mg} / \mathrm{l}$ ) were recorded in plants irrigated with water containing nickel concentration of (300 mg/l), whereas the highest values of transfer factor in leaves (0.998 and 0.986 $\mathrm{mg} / \mathrm{l})$, stem $(0.596$ and $0.637 \mathrm{mg} / \mathrm{l})$ and root $(0.460$ and $0.476 \mathrm{mg} / \mathrm{l})$ were registered in plants irrigated with tap water (control). 
Table 9. Average values of nickel content in soil samples as influenced by nickel concentrations in irrigation water and foliar application of citric acid on Lantana camara in the two seasons of 2018 and 2019.

\begin{tabular}{|c|c|c|c|c|c|}
\hline \multicolumn{2}{|c|}{ Treatments } & \multicolumn{4}{|c|}{ Nickel content in soil (mg/kg) } \\
\hline \multirow{2}{*}{$\begin{array}{l}\text { Nickel } \\
\text { (mg/l) }\end{array}$} & \multirow{2}{*}{$\begin{array}{c}\text { Citric acid } \\
(\mathrm{mg} / \mathrm{l})\end{array}$} & \multicolumn{2}{|c|}{2018} & \multicolumn{2}{|c|}{2019} \\
\hline & & Before & After & Before & After \\
\hline & $\mathbf{0}$ & 0.016 & 0.085 & 0.016 & 0.089 \\
\hline \multirow[t]{3}{*}{$\mathbf{0}$} & 250 & 0.017 & 0.095 & 0.019 & 0.104 \\
\hline & 500 & 0.026 & 0.142 & 0.028 & 0.149 \\
\hline & 0 & 0.078 & 0.416 & 0.011 & 0.439 \\
\hline \multirow[t]{3}{*}{100} & 250 & 0.075 & 0.402 & 0.079 & 0.422 \\
\hline & 500 & 0.072 & 0.388 & 0.076 & 0.409 \\
\hline & 0 & 0.058 & 0.734 & 0.065 & 0.775 \\
\hline \multirow[t]{3}{*}{200} & 250 & 0.048 & 0.681 & 0.055 & 0.717 \\
\hline & 500 & 0.038 & 0.629 & 0.044 & 0.664 \\
\hline & 0 & 0.017 & 0.943 & 0.027 & 0.995 \\
\hline \multirow[t]{2}{*}{300} & 250 & 0.012 & 0.917 & 0.022 & 0.968 \\
\hline & 500 & 0.015 & 0.888 & 0.016 & 0.937 \\
\hline
\end{tabular}

Table 10. Mean values of transfer factor to leaves, stem and roots of Lantana camara plants as influenced by nickel (Ni), citric acid (CA) and their combinations $(\mathrm{Ni} \times \mathrm{CA})$ in the two seasons of 2018 and 2019.

\begin{tabular}{|c|c|c|c|c|c|c|c|}
\hline \multicolumn{2}{|c|}{ Treatments } & \multirow{2}{*}{\multicolumn{2}{|c|}{$\begin{array}{l}\text { Transfer factor to } \\
\text { leaves (TFL) }\end{array}$}} & \multirow{2}{*}{\multicolumn{2}{|c|}{$\begin{array}{c}\text { Transfer factor to } \\
\text { stem (TFS) }\end{array}$}} & \multirow{2}{*}{\multicolumn{2}{|c|}{$\begin{array}{c}\text { Transfer factor to } \\
\text { root (TFR) }\end{array}$}} \\
\hline $\begin{array}{l}\text { Nickel } \\
\text { (mg/l) }\end{array}$ & $\begin{array}{c}\text { citric acid } \\
(\mathrm{mg} / \mathrm{l})\end{array}$ & & & & & & \\
\hline & 0 & 1.811 & 3.494 & 1.705 & 1.887 & 0.717 & 0.539 \\
\hline \multirow[t]{2}{*}{$\mathbf{0}$} & 250 & 0.968 & 2.423 & 1.505 & 1.596 & 0.600 & 0.423 \\
\hline & 500 & 0.429 & 1.516 & 0.978 & 0.979 & 0.359 & 0.255 \\
\hline \multirow[t]{2}{*}{ Mean (Ni) } & & 1.069 & 2.477 & 1.396 & 1.487 & 0.558 & 0.405 \\
\hline & $\mathbf{0}$ & 1.144 & 1.441 & 0.831 & 0.947 & 0.641 & 0.731 \\
\hline \multirow[t]{2}{*}{100} & 250 & 1.139 & 1.457 & 0.840 & 0.966 & 0.649 & 0.746 \\
\hline & 500 & 1.067 & 1.398 & 0.819 & 0.948 & 0.634 & 0.733 \\
\hline \multirow[t]{2}{*}{ Mean (Ni) } & & 1.116 & 1.432 & 0.830 & 0.953 & 0.641 & 0.736 \\
\hline & $\mathbf{0}$ & 1.155 & 1.090 & 0.696 & 0.659 & 0.536 & 0.508 \\
\hline \multirow[t]{2}{*}{200} & 250 & 1.198 & 1.133 & 0.729 & 0.690 & 0.565 & 0.534 \\
\hline & 500 & 1.265 & 1.207 & 0.775 & 0.739 & 0.599 & 0.570 \\
\hline \multirow[t]{2}{*}{ Mean (Ni) } & & 1.206 & 1.143 & 0.733 & 0.696 & 0.566 & 0.537 \\
\hline & $\mathbf{0}$ & 0.978 & 0.973 & 0.594 & 0.632 & 0.459 & 0.464 \\
\hline \multirow[t]{2}{*}{300} & 250 & 0.994 & 0.997 & 0.588 & 0.633 & 0.454 & 0.476 \\
\hline & 500 & 1.023 & 0.990 & 0.606 & 0.648 & 0.467 & 0.490 \\
\hline \multirow[t]{2}{*}{ Mean (Ni) } & & 0.998 & 0.986 & 0.596 & 0.637 & 0.460 & 0.476 \\
\hline & $\mathbf{0}$ & 1.272 & 1.749 & 0.956 & 1.031 & 0.588 & 0.560 \\
\hline \multirow[t]{2}{*}{ Mean (MA) } & 250 & 1.074 & 1.502 & 0.915 & 0.971 & 0.567 & 0.544 \\
\hline & 500 & 0.946 & 1.277 & 0.794 & 0.828 & 0.514 & 0.512 \\
\hline
\end{tabular}

Data in Table (10) showed also that the transfer factor (TF) in the dried plant parts was steadily reduced with increasing citric acid concentration. Accordingly, the highest nickel values in leaves (1.272 and 1.749 $\mathrm{mg} / \mathrm{l})$, stem (0.956 and $1.031 \mathrm{mg} / \mathrm{l})$ and root ( 0.588 and $0.560 \mathrm{mg} / \mathrm{l})$ were recorded in the leaves of control plants, whereas plants sprayed with the highest citric acid concentration (500 mg/l) had the lowest nickel values in leaves (0.946 and 1.277 $\mathrm{mg} / \mathrm{l})$, stem $(0.794$ and $0.828 \mathrm{mg} / \mathrm{l})$ and root ( 0.514 and $0.512 \mathrm{mg} / \mathrm{l})$ of the two seasons, respectively.

\section{DISCUSSION}

All vegetative growth parameters showed significant reduction after treatment 
with the different concentrations of nickel in irrigation water. These may be due to that $\mathrm{Ni}$ has some similar characteristics to $\mathrm{Ca}, \mathrm{Mg}$, $\mathrm{Mn}, \mathrm{Fe}, \mathrm{Cu}$, and $\mathrm{Zn}$. Therefore, nickel may compete with these metals in absorption and transpiration processes (Küpper et al., 1996). Subsequently, this may affect important physiological processes, and ultimately result in toxic effects (Goncalves, 2007). For example, $\mathrm{Ni}$ can decrease $\mathrm{Mg}$ (or Fe) uptake and then induce deficiencies of these elements in plants. This may result in the retardation of germination, growth suppression, and reductions in yields (Seregin and Kozhevnikova, 2006). These results are in harmony with those obtained by MadhavaRao and Sresty (2000) on Cajanus cajan, Pandey and Sharma (2002) on cabbage and Eman et al. (2007) on Hibiscus sabdariffa.

A significant decrease in total chlorophyll content was observed after irrigation with nickel polluted water. Diminished chlorophyll concentration in the leaves of nickel treated plants might be due to replacement of central $\mathrm{Mg}$ from chlorophyll molecules by nickel (Küpper et al., 1996). Further, decline in chlorophyll concentration (Gajewska et al., 2006) in leaves of nickel treated plants may also be attributed to increase interruption in pigment synthesis and/or increase in degradation of chlorophyll (Sheoran et al., 1990) and (Molas,1997) ultimately leading to low photosynthetic rates and lower biomass accumulation. Along with the interference in chlorophyll biosynthesis, nickel may also damage the thylakoid membrane and chloroplast grana structure (Molas, 2002), reducing the size of grana (Seregin and Kozhevnikova, 2006). These results are in agreement with the results reported by (Prasad et al., 2005) on Glycine max (L.) under nickel stress.

The results showed that there was a significant decrease in total carbohydrates percentage after irrigation with nickel contaminated water. This decrease may be due to reductions in leaf blade area and leaf density (Molas, 1997). Overall, reductions in plant yield can be attributed to poor plant development (Ahmad et al., 2007). These results are in harmony with those were obtained by (Srivastava et al., 2012) on Pisum sativum L. seedlings.

The increase in nickel content in dried leaves and roots is probably because plant shaves efficient root absorption mechanisms which allow them to specifically accumulate metals from soils and/or water. After root absorption, nickel can be transported quickly into shoots and leaves and then sequestrated in the vacuole (Milner and Kochian, 2008). These results are in agreement with those reported by (Skoula et al., 2003) on chamomile, sage (Salvia officinalis) and thymus (Thymus vulgaris).

For the effect of citric acid, it is observed that there is a significant increase in all vegetative parameters, chlorophyll content, carbohydrate percentage, significant decrease in nickel content in leaves and roots and decrease in nickel content in soil samples. This may be due to that application of citric acid with any of the concentrations of nickel led to a statistically decrease in the uptake of nickel. This decrease in the uptake of nickel in the presence of citric acid resulted in the formation of citric acid-nickel complexes that inhibited the uptake (Chen et al., 2003). The decrease in nickel uptake helped to overcome the negative effects of $\mathrm{Ni}$ on the previous studied parameters. These results are in agreement with those mentioned by (Talebi et al., 2014) on Gazania plants and (Jaafari and Hadavi, 2012) on Ocimum basilicum L.

Concerning treatments, at a preliminary stage, one should note that the transfer factor (TF) of most treatments is lower than one for nickel; which means that the physiological need of the plant for this element is rather limited. Translocation from roots to shoots via a number of physiological processes, including metal unloading into root xylem cells, long-distance carrying from the xylem to the shoots and metal reabsorption, by leaf mesophyll cells, from the xylem stream. 
Once the nickel has been unloaded into the xylem vessels, the metals are carried to the shoots by the transpiration stream (Blaylock and Huang, 2000). Confirming the previous results (El-Shanhorey and EL-Sayed, 2017) on Senecio cineraria and (El-Shanhorey and Emam, 2016) on Jatropha curcas.

\section{CONCLUSION}

Phytoremediation is a new cleanup concept that involves the use of plants to clean or stabilize contaminated environments. Phytoremediation of metals is the most effective plant-based method to remove pollutants from contaminated areas. This green technology can be applied to remediate the polluted soils without creating any destructive effect of soil structure. Some specific plants, such as woody species, have been proven to have noticeable potential to absorb toxic heavy metals.

We conclude that we can use Lantana camara plants as nickel phytoremediation plant without spraying with citric acid and if we want to use Lantana camara as an ornamental plant and the irrigation water is polluted with nickel we can spray the plants with citric acid to overcome the negative effect of nickel.

\section{REFERENCES}

Ahmad, M.S.A.; Hussain, M.; Saddiq, R. and Alvi, A.K. (2007). Mungbean: A nickel indicator, accumulator or excluder?, Bull. Environ. Contam.Toxicol., 78:319-324.

Ashwini, A.; Swati, K. and Sujata, G. (2014). Evaluation of phytoremediation potential of Lantana camara for heavy metals in an industrially polluted area in Bhopal, India. International Journal of Engineering and Applied Sciences, 1(2):1-3.

Bates, L.S.; Waldern, R.P. and Teare, L.D. (1973). Rapid determination of free proline under water stress studies. Plant and Soil, 39:205-207.

Blaylock M.J. and Huang, J.W. (2000). Phytoextraction of metals.
Phytoremediation of Toxic Metals: Using Plants to Clean Up the Environment. Eds., Raskin, I. and B.D. Ensley. John Wiley and Sons, Inc, Toronto, 303 p.

Chen, Y.; Shen Z. and Li, X. (2004). The use of vetiver grass (Vetiveria zizanioides) in the phytoremediation of soils contaminated with heavy metals. Applied Geochemistry, 19:1553-1565.

Chen, Y.X.; Lin, Q.; Luo, Y.M.; He, Y.F.; Zhen, S.J.; Yu, Y.L.; Tian, G.M. and Wong, M.H. (2003). The role of citric acid on the phytoremediation of heavy metal contaminated soil. Chemosphere, 50:507-811.

Choruk, K.; Kurukote, J.; Supprung, P. and Vetayasuporn, S. (2006). Perennial plants in the phytoremediation of leadcontaminated soils. Biotechnology, 5(1):1-4.

Da Silva, J.A.T. (2003). The cut flower: postharvest considerations, J. Biol. Sci., 3(4):406-442.

Duarte, B.; Delgado, M. and Cador, I. (2007). The role of citric acid in cadmium and nickel uptake and translocation, in Halimione portulacoides. Chemosphere, 69:836840.

Dubios, M.; Gilles, K.; Hamlton, J.; Rebers, P. and Smith, F. (1956). Colourimetric method for determination of sugars and related substances. Analytical Chemistry, 28(3):350- 356.

El-Shanhorey, N.A. and Emam, K.A. (2016). Response of Jatropha curcas plants to foliar applied ascorbic acid for decreasing the harmful effect of nickel pollution in the irrigation water. Alex. J. Agric. Sci., Alex. Univ., 61(3): 221-235.

El-Shanhorey, N.A. and El-Sayed, S.G. (2017). The use of Senecio cineraria plants sprayed with citric acid for nickel pollution phytoremediation. Alexandria Science Exchange Journal, 38(2):343355. 
Eman, A.E.; Gad, N. and Badran, N.M. (2007). Effect of cobalt and nickel on plant growth, yield and flavonoids content of Hibiscus sabdariffa L. Aus. J. Basic Appl. Sci., 1:73-78.

Gajewska, E.; Sklodowska, M.; Slaba, M. and Mazur, J. (2006). Effect of nickel on antioxidative enzyme activities, proline and chlorophyll contents in wheat shoots. Biol. Plant, 50(4):653-659.

Goncalves, S.C. (2007). Genetic diversity and differential in vitro responses to $\mathrm{Ni}$ in Cenococcum geophilum isolates from serpentine soils in Portugal. Mycorrhiza, 17:677-686.

Jaafari, N. and Hadavi, E. (2012). Growth and essential oil yield of Basil (Ocimum basilicum L.) as affected by foliar spray of citric acid and salicylic acid. Zeitschrift fur Arznei-und Gewurzpflanzen, 17(2):80-83.

Jackson, N.L. (1958). Soil Chemical Analysis. Constable. Ltd. Co., London, $498 \mathrm{p}$.

Karam, N.S. (1998). Metal concentrations, growth, and yield of potato produced from in vitro plantlets or microtubers and grown in municipal solid-waste amended substrates, J. Plant Nutr., 21:725-739.

Koller, H.R. (1972). Leaf area, leaf weight relationship in the soybean canopy. Crop Sci., 12:180-183.

Küpper, H. and Kroneck, P.M.H. (2007). Metal ions in life sciences (Eds: A. Sigel, H. Sigel, R.K.O. Sigel), Vol. 2, John Wiley\& Sons, Chichester, UK., pp. 3162.

Küpper, H.; Küpper, F. and Spiller, M. (1996). Environmental relevance of heavy metal substituted chlorophyll using the example of water plants. J. Exp. Bot., 47:259-266.

Lindsay, W.L. and Norvell, W.A. (1978). Development of a DTPA soil test for zinc, iron, manganese and copper. Soil Sci. Soc. Am. J., 42:421-428.
MadhavaRao, K.V. and Sresty, T.V. (2000). Antioxidative parameters in the seedlings of pigeon pea (Cajanus cajan (L.) Millspaugh) in response to $\mathrm{Zn}$ and $\mathrm{Ni}$ stresses. Plant Sci., 157:113-128.

Milner, M.J. and Kochian, L.V. (2008). Investigating heavy-metal hyperaccumulation using Thlaspi caerulescens as a model system. Ann. Bot.,102:3-13.

Molas, J. (1997). Changes in morphological and anatomical structure of cabbage (Brassica oleracera L.) outer leaves and in ultrastructure of their chloroplasts caused by an in vitro excess of nickel. Photosynth., 34:513-522.

Molas, J. (2002). Changes of chloroplast ultra structure and total chlorophyll concentration in cabbage leaves caused by excess of organic Ni (II) complexes. Environ. Exp. Bot., 47:115-126.

Mulrooney, S.B. and Hausinger, R.P. (2003). Nickel uptake and utilization by microorganisms. FRMS Microbiol, Rev., 27:239-261.

Pandey, N. and Sharma, C.P. (2002). Effect of heavy metals $\mathrm{Co}^{2+}, \mathrm{Ni}^{2+}$ and $\mathrm{Cd}^{2+}$ on growth and metabolism of cabbage. Plant Sci., 163(4):753-758.

Piper, O.S. (1947). Soil and Plant Analysis. Adelaite University, Adelaide, Australia, pp. 258-275.

Prasad, S.M.; Dwivedi, R. and Zeeshan, M. (2005). Growth, photosynthetic electron transport, and antioxidant responses of young soybean seedlings to simultaneous exposure of nickel and UV-B stress. Photosynthetica., 43:177-185.

Ragsdale, S.W. (1998). Nickel biochemistry. Curr. Opin. Chem. Biol., 2:208-215.

Salt, D.E. (2000). Phytoremediation of contaminated soil and water. (Eds. N. Terry. G. Banuelos). Lewis Publishers. Boca Raton., Fl., pp. 189-200.

SAS Institute (2002). SAS User Guide and Program 20 Version 9.0.38. Cary, North Carolina, USA. 
Seregin, I.V. and Kozhevnikova, A.D. (2006). Physiological role of nickel and its toxic effects on higher plants. Russ. J Plant Physiol., 53(2):257-277.

Sharma, B.D.; Mukhopadhyay, S.S. and Katyal, J.C. (2006). Distribution of total and DTPA-extractable zinc, copper, manganese and iron in vertisols of India. Commun Soil Sci. Plant Anal., 37:653672.

Sheoran, I.S.; Singal, H.R. and Singh, R. (1990). Effect of cadmium and nickel on photosynthesis and enzymes of the photosynthetic carbon reduction cycle in pigeon pea (Cajanus cajan L.). Photosynth. Res., 23:345-351.

Skoula, M.; Fabian, M. and LydakisSimantiris, N. (2003). Cadmium, nickel, and lead accumulation in chamomile, thyme and sage, grown on heavy metalenriched soil. In: Proceedings of the $2^{\text {nd }}$ European Bioremediation Conference, Chania, Greece, pp. 329-332.

Snedecor, G.W. and Cochran, W. (1989). Statistical Methods, $8^{\text {th }}$ ed. Edition, Iowa State University Press. Ames. Iowa. USA, $491 \mathrm{p}$.

Srivastava, G.; Kumar, S.; Dubey, G.; Mishra, V. and Prasad, S.M. (2012). Nickel and ultraviolet-B stresses induce differential growth and photosynthetic responses in Pisum sativum L. seedlings. Biol. Trace, 149(1):86-96.

Talebi, M.; Hadavi, E. and Jaafari, N. (2014). Foliar sprays of citric acid and malic acid modify growth, flowering, and root to shoot ratio of gazania (Gazania rigens L.): A comparative analysis by ANOVA and structural equations modeling. Adv. Agric. Article ID, 147278:1-6.

Taize, L. and Zeiger, E. (2002). Plant Physiology, $\quad 3^{\text {rd }}$ Edition. Sinauer Associates Inc., Sunderland, MA, USA. $291 \mathrm{p}$.

Wills, R.; Lee, T.; Graham, D.; McGlasson, W. and Hall, E. (1981). Post-Harvest: An Introduction to the Physiology and Handling of Fruit and Vegetables. Kensington, NSW, New South Wales Univ. Press, United Kingdom, 161 p.

Wua, G.; Kanga, H.; Zhangc, X.; Shaob, H.; Chuc, L. and Ruand, C. (2010). A critical review on the bio-removal of hazardous heavy metals from contaminated soils: Issues, progress, eco-environmental concerns and opportunities. J. Haz. Mat., $174: 1-8$.

Yadava, U. (1986). A rapid and nondestructive method to determine chlorophyll in intact leaves. Hort. Sci., 21(6):1449-1450.

\footnotetext{
إستجابة نباتات اللانتانا للاش بحمض الستريك لتقليل الأثر الضار

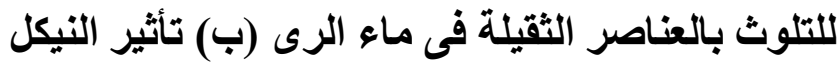

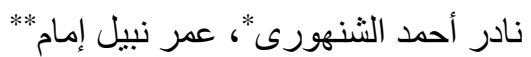

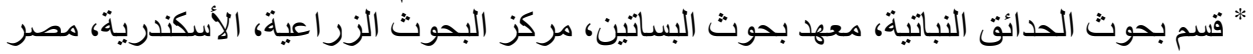

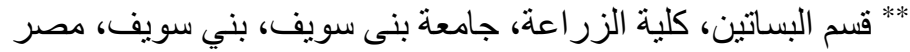

أجريت هذه الدراسة في فرع البحوث بأنطونيادس، معهد بحوث البساتين، مركز البحوث الزر اعبية، الإسكندرية،

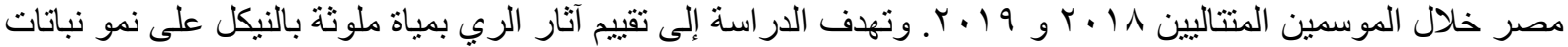

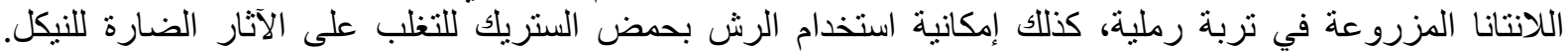

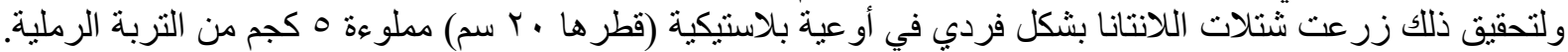

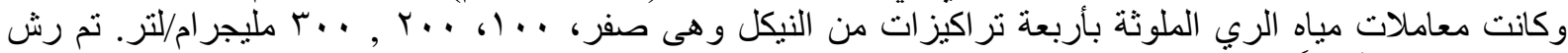

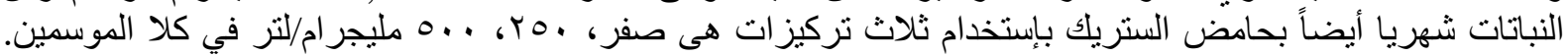

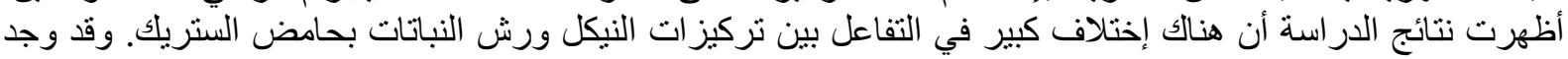

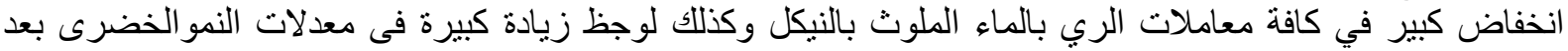




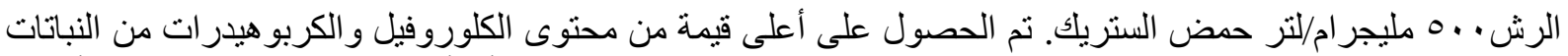

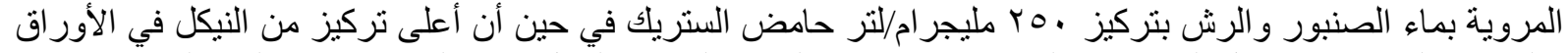

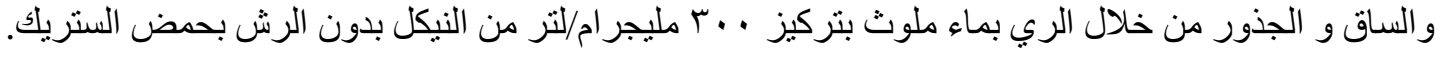

